\title{
Pre-rifting volatile-rich melts and asthenosphere influxes: The alkaline- carbonatitic lamprophyres of the Southern Alps (NE Italy)
}

\author{
F. CASETTA ${ }^{1 *}$, R.B. ICKERT ${ }^{2,3}$, D.F. MARK ${ }^{3}$, C. \\ BONADIMAN $^{1}$, P.P. GIACOMONI ${ }^{1}$, T. NTAFLOS ${ }^{4}$ AND M.
} COLTORTI $^{1}$

${ }^{1}$ Department of Physics and Earth Science, University of Ferrara, Via Saragat 1, 44121 Ferrara, Italy

(*correspondence: cstfrc@unife.it)

${ }^{2}$ Department of Earth, Atmospheric, and Planetary Sciences College of Science, Purdue University, 550 Stadium Mall Dr., West Lafayette, IN 47907, USA (ickert@purdue.edu) ${ }^{3}$ SUERC, Scottish Enterprise Technology Park, Rankine Av., East Kilbride, G75 0QF, UK

(Darren.Mark@glasgow.ac.uk)

${ }^{4}$ Department of Lithospheric Research, Universitat Wien, Althanstraße 14 (UZA II), 1090 Wien, Austria

(theodoros.ntaflos@univie.ac.at)

The opening of major magmatic cycles is often anticipated by the extrusion of alkaline and volatile-rich magmas. Lamprophyres are of particular interest in this context, since they represent alkali-, $\mathrm{H}_{2} \mathrm{O}$ and $\mathrm{CO}_{2}$-bearing melts generated in deep enriched Sub-Continental Lithospheric Mantle domains.

The camptonitic dykes cropping out in the Dolomitic Area (NE Italy) are among the oldest lamprophyres in Italy, and were historically related to the orogenic-like magmatism that shaped the Southalpine domain during Middle Triassic ( $\sim 238$ Ma). Petrological, geochemical and geochronological data show that these rocks emplaced at $\sim 220 \mathrm{Ma}$, and were likely produced by low partial melting degree of a garnet-amphibolebearing mantle source interacting with asthenospheric components. We hypothesize that the lamprophyres of the Dolomitic Area belong to the alkaline-carbonatitic pulse that infiltrated several portions of Southalpine lithosphere between 225 and 190 Ma.

These new findings led us to interpret these lamprophyres as the geochemical/geochronological connection between the orogenic-like Middle Triassic magmatism and the rifting phase related to the opening of the Alpine Tethys. This study underlines the role played by the volatiles during large-scale geodynamic processes. 